\title{
Islam Nusantara In Islamic Law Epistemology Perspective
}

\author{
Maimun \\ (Jurusan Tarbiyah STAIN Pamekasan, Jl. Raya Panglegur Km. 4, \\ Email:maimunmuhammad84@yahoo.com)
}

\begin{abstract}
Abstrak:
Islam Nusantara merupakan tendensi keberagamaan yang bersifat geografis, yaitu Islam konteks Indonesia, yang mulai populer sejak tahun 2015 dengan momentum Muktamar NU ke-33 di Jombang. Konsep ini melahirkan respon pro dan kontra karena dinilai menyimpang dari tuntunan Rasulullah. Oleh karenanya terbersit keinginan untuk mengkaji konsep ini secara epistemologis untuk menemukan konsep yang utuh melalui kajian kepustakaan. Ada dua rumusan yang mewakili kajian ini; pertama, bagaimana dasar epistemologi Islam Nusantara serta implikasinya secara sosiologis. Kedua, bagaimana konsep Islam Nusantara dalam pandangan epistemologi hukum Islam (Usul Fiqh). Dari literatur yang ada, dapat ditemukan; pertama, konsep ini merupakan produk pemikiran kalangan Nahdlatul Ulama' dengan berpedoman pada nilai perjuangan Ahlussunah wal Jama'ah serta gerakan Islamisasi yang dilakukan Wali Songo di tanah Jawa. Implikasinya adalah terbentuknya pendekatan kebudayaan yang berupaya melakukan internalisasi nilai Islam dalam budaya setempat serta membentuk karakter yang moderat dan penuh toleransi. Kedua, Islam Nusantara bukanlah konsep yang keluar dari Islam, karena dalam Islam juga dikenal bangunan epistemologi hukum ('urf) yang memberikan ruang pada budaya lokal untuk bisa dijadikan hukum selama tidak bertentangan dengan dalil nash.
\end{abstract}

\section{Kata-kata Kunci:}

Epistemologi, Islam Nusantara, dan Hukum Islam

\begin{abstract}
:
Islam Nusantara is a geographical religious tendencies representing Indonesian context. This term has become popular since 2015 by The 33th congress (Muktamar) of NU in Jombang. This concept creats variance responses between pro and contra estimated as deviative concept from the guidance of Prophet Muhammad. Therefore it appears a desire to examine this concept epistemologically to find a
\end{abstract}

al-1hkâm Vol.11 No.2 Desember 2016 DOI 10.19105/al-ihkam.v11i2.779 
holistical concept, through the study of literature. There are two problems representing this study; First, how is the basic epistemology of Islam Nusantara and its sociological implication. Second, how is the Islam Nusantara in the view of Islamic law (usul fiqh). Based on these problems, it can be found some conclusion; first, this concept is a product of thought of Nahdlatul Ulama' based on their struggle value, ahl al-sunnah wa al-jamâ'ah (aswaja) and the Islamization movement conducted by walisongo in Java. The implication of this pattern is moderation, tolerance, and awareness of nations plurality tendency. Secondly, Islam Nusantara is not wrong concept coming out of Islam, moreover in Islam itself also known a building of Islamic law epistemology ('urf) giving special space on local culture to be a law as long as does not digress from axiomatic Islamic text.

\section{Key Words: \\ Epistemology, Islam Nusantara, dan Islamic law}

\section{Introduction}

As far as civilization has begun, 'belief' has become synonymous integral part of cultural unity of the human historicity, although in very simple form such as animism and dynamism. ${ }^{1}$ In the course of belief, religion emerged as a more perfect transformation form with overall normativity in the nature that constantly get in contact with a cultural dimension.

Islam as religion that is considered transcending cultural boundaries, estimated more 'complecated' as revealed by God for all mankind in the world, as well as the cover other heavenly religious treatise. This category increasingly demands that Islam should be acceptable in any space and time. This demand is not solely mediate treatise character that should be conveyed but also because religion is identical part of the human community.

There are some interaction and dynamic relationships that have recorded in history between universal Islamic teachings to the local

1These animism and dynamism become Javanese beliefs before receiving the influence of Hindu's religion and culture. They worship the spirits of ancestors, and believe in magical powers contained in objects, trees, animals which are considered having mana: a supernatural power. Syamsun Ni'am, Pesantren: The Miniature of Moderate Islam in Indonesia, IJIMS (Indonesian Jurnal of Islam and Muslim Societies), volume 5, 1 Juni 2015, 114 
culture and tradition of community, such as the Arab region, as the first Islamic spatial locus. Just over 23 years Islam has spread out to overall regions of the Arabian Peninsula, and this Islamisation process has been completed before the prophet Muhammad died in 632 at the age 63 years old. ${ }^{2}$

In its journey, the development and Islamic spreading extend beyond the border of Arab territories surpass upon various continents in the world. In a relatively short time, Islam emerges as a dynamic political force, meliter, economic and new social culture in the world history dealing with the Persian Empire and Byzantium. ${ }^{3}$ In these areas, Islam comes with a fact that there has been already tradition and local culture that has grown and rooted in the community life. therefore, it can be highlighted the additional demands that Islamic arrival can not be separated from the surrounded culture and people traditions, and get mutual interaction within the framework of internalization and syncretization process of Islamic teachings to the local culture. Including when Islam arrives at our country, Indonesia, a region that has quite far mileage and time from the Islamic origin area, and thus there is logical consequence today about a fact that we can find, various faces of Islam as perceived geographically, such as Islam of Middle east (read: Arabs), European Islam, Turkish Islam, Chinese, Islam of Indonesia (read: Islam Nusantara) and others with a different character.

Therefore, on this framework bases, the author intends to examine the epistemology of Islam Nusantara deeply and also its implication in Islamic juridical paradigm by focusing as follows; First, how about the epistemology of Islam Nusantara and its sociological implications. Secondly, how about the concept of Islam Nusantara in the view of Islamic law epistemology (usul fiqh). In answering this focuses the author gets some related literatures as impoetant source that analyzed correlatively.

2Faisal Ismail, Pijar-Pijar Islam, Pergumulan Kultur Dan Struktur, (Jakarta: Badan Litbang Agama dan Diklat Keagamaan, tt.), 4

3Ibid., 5. The Persian empire was in Iran and Byzantium area in the eastern of Roman Byzantine society that throughout history often think themselves as Roman nation, foretold by Qur'an the defeat and resurgence within a few years later. Syed Mahmudunnasir, Islam: Konsep dan Sejarahnya, (Bandung: PT. Remaja Rosdakarya, 2011), 378 


\section{The Epistemology of Islam Nusantara}

Conceptually, epistemology is a study of knowledge relating to the origin, type, nature, and science substance explored to find the source of knowledge and its relation to the truth and conviction. ${ }^{4}$ While, Islam nusantara is geographical identity of Islam in Indonesia. Namely, Islam that come in Indonesia and its culture to richen and perfect it. 5

Thus, Islam Nusantara is a focus study that attempted to explore the Indonesian Islamic concept in depth, about the root and source of its history. In its appearance, the term of Islam Nusantara became booming issue becouse it was made as central theme at the congress moment of Nahdliyin in Jombang in 2015. Nahdlatul Ulama' (Awakening Ulama or Islamic Scholars), often known as NU, is an Islamic organization in Indonesia that was established on January 31, 1926 and wrestled educational, social, and economic field. ${ }^{6}$ As the largest Islamic organization in Indonesia, NU has been playing a significant role in carrying Islamic tolerant and peaceful ideas. This moderation value become their attitude fundmentally inseparable from the faith of ahl al-sunnah wa al-jamâ'ah (aswaja) as organization struggles reference and based value. ${ }^{7}$

In their association articles mentioned that NU as Jam'iyah Diniyah Islâmiyah based on Islamic principle of ahl al-sunnah wa aljamâ'ah that refers to the four schools in fiqh, namely Hanafi, Maliki, Shafi'i and Hanbali, they refer to Imam Abû Hasan al-Ash'ari and

\footnotetext{
"In etimological term, Epistemology is derived from the word "episteme," which means "knowledge" and "logos" which means "science". In terminological term it is part of philosophy that oriented in the discussion about the source, structure, originality, understanding, methods and the validity of knowledge, therefore it origin and derivation can be tracked. See, Ali Maksum, Pengantar Filsafat, (Jogjakarta: arRuzz Media, 2011), 36.

${ }^{5}$ Rofii Boenawi, Inilah Calon Pemimpin Kita, (Surabaya: PT Aula Media Nahdlatul Ulama), Majalah Nahdlatul Ulama' AULA edisi Juli 2015, 12-13.

${ }^{6}$ Andree Feillar, NU vis a vis Negara, (Yogyakarta: LkiS, 1999), 7

${ }^{7}$ Ahmad Zainol Hamid, NU Dalam Persinggungan Ideologi; Menimbang Ulang Moderasi Keislaman Nahdhatul Ulama', Tashwirul Afkar Number Edition 21 Tahun 2007, 28
} 
Imam Abû Mansour al-Maturidi In theology. In other hand, they tend to the thought of al-Junaid al-Baghdadî and al-Ghazalî in Sufism. ${ }^{8}$

Fundamentally the terms of ahl al-sunnah wa al-jamâ'ah can be interpreted as "the followers of tradition of Prophet Muhammad and ijmâ '(agreement) scholars'" in moderate carracter (tawassuth), being fair (i'tidâl), being balance (tawâzun), and being tolerant (tasâmuh), they refuse any extreme forms of action and thought (tatharruf) which can rise irregularities and misappropriation of Islamic teachings, while maintaining balance (the middle way) between using revelation (naqliyah) and logical ratio ('aqliyah), that really possible to find an accommodation and convergence condition for the change in society as long as not against the dogmatic doctrines. In the view of ahl alsunnah wal jamấah. Tradition maintaining has an important meaning in religious life, till the tradition is not removed entirely, also not accepted in whole, but trying gradually filled with the Islamic values. ${ }^{9}$

This approach is inspired persuasive ways developed by Walisongo in clicking Islamized Java island and replace HinduBuddhist power in sixteenth and seventeenth centuries. ${ }^{10}$ In delivering this mission, the trustees so physically involved in social role to introduce, explain, and solve the problems of society.

Some Examples that can be presented are the internalization process of Islamic value against tradition of puppet play that become habits for Javanese people. After Islam comes to Indonesia, puppet play is substantially directed to be even messier. It is coused by the understanding that Islam does not recognize trine term and deities pantheistic system. The guardians (walisongo), especially Sunan Kalijaga, changed divine hierarchy system that puts the gods (deities) only as the executor of God's order, not as truely God and then it's internalized by purification process carried out to highlight the dominant teachings and values of Islam. So, they formulated new

8Mujamil Qomar, NU Liberal; Dari Tradisionalisme Ahlussunnah Ke Universalisme Islam, (Bandung: Mizan, 2002), 62

9Ibid.

10Abdurrahman Mas'ud, Intelektual Pesantren: Perhelatan Agama Dan Tradisi, (Yogyakarta: LKiS, 1994), 9 
stories related to Islamic value, such as The play of Dewaruci, fetish of Kalimasada, and play of revelation. ${ }^{11}$

In other hand, Sunan Muria also performed using the same approach as his father, Sunan Kalijaga. He did not unload the tradition at all, but renewed and given by islamic value, such as the salvation ceremony that held by Javanese at that time.12 This is a perfect modeling ${ }^{13}$ that has brought them to the status as right sole interpreter based on two main sources of Islam: al-Quran and Sunnah, which in the next period delivered to further generation in the tradition of pesantren initiated by Mawlana Malik Ibrahim (d. 1419 in Gresik, East Java). ${ }^{14}$

The implications of this modeling displays Islamic characters on which according Azyumardi Azra, including; pluralism, tolerance, moderation and cultural approach. ${ }^{15}$ Pluralism is an interaction framework of several groups that show mutual respect. They live together (coexistence) and produce some results without conflict. Substantially this sense is manifested in the attitude of mutual recognition, mutual respect, and care each other in a harmonious togetherness frame. ${ }^{16}$ Tolerance is the ability to respect the nature, beliefs, and behaviors owned by others. In Islamic literature, tolerance known as tasâmuh that understood as nature or attitude of respect, let

11Purwadi, Dakwah Sunan Kalijaga; Penyebaran Agama Islam di Jawa Dengan Berbasis Kultural, (Yogyakarta: Pustaka Pelajar), 5

12Ridin Sofwan, dkk., Islamisasi di Tanah Jawa; Walisongo Penyebar Islam di Jawa Menurut Penuturan Babad, (Yogyakarta: Pustaka Pelajar, 2000), 158

${ }^{13}$ Modeling is Albert Bandura's theory, a Canadian behavioristik figure (born 1925) about learning. He asserted that learning requires figures or examples or models. Such as parents, teachers or other influential figures. This model able to be reflected in daily ideal life. See, Jess Feist dan Gregory. J. Feist, Theories of Personality, Teori Kepribadian, terj. Smita Prathita Sjahputri (Jakarta: Salemba Humanika, 2010), 240.

14Abdurrahman Mas'ud, Dari Haramain ke Nusantara Jejak Intelektual Arsitek Pesantren, (Jakarta: Kencana Prenada Media Group, 2006), 62

${ }^{15}$ Azyumardi Azra, Asia Tenggara Konsentrasi Baru Kebangkitan Islam, (Bandung: Fokusmedia, 2003), 116

16Pluralism term is very different from the pluralism debated and rejected by MUI considering that all religions are the same and relative. According to Kuntowijoyo this pluralism mantioned as a type of positive pluralism, the religious attitude promoting respect and appreciation of the opinion, the choices of life and religious beliefs. Kuntowijoyo, Muslim Tanpa Masjid: Esai-Esai Agama, Budaya dan Politik Dalam Bingkai Strukturalisme Transendental, (Bandung: Mizan, 2001), 287 
or allow the other person's contention that contrary to our view. In other words, tolerance is the belief that religious diversity occurs because of history with all it influence factors, wether the condition of space, time, prejudice, desire, and interest that differ from one to others. ${ }^{17}$

Azyumardi Azra consider that Islam Nusantara like those of NU and Muhammadiyah has almost all progress potention to realize great civilization as rahmatan lil'alamin. Some of the institution richness and diversity such as mosques, schools, Islamic boarding schools, colleges, hospitals, clinics, and other economic enterprises become tangible manifestation of the owned amount capital. Based on this case, there are many foreign people since the late of 1980 s such as Fazlur Rahman estimated great potential of Islam nusantara to stand foremost in advancing the global Islamic civilization. By Islamic civilization of wasathiyah (middle path) Islam Nusantara can contribute more peaceful and harmony for the world civilization. This expectation has increased around continueing conflict in muslim countries of the Arab world, South Asia, West Asia, and Africa. So that, entire Muslim organizations of wasathiyah not only need to improve thinking and charitable efforts in the country, but also be more expansive in spreading Islam wasathiyah to foreign countries, and be more expansive ward to other country, till Islam nusantara can stand at the forefront in realizing Islam as Rahmatan lil' âlamin. ${ }^{18}$

On the other hand, Abdurrahman Wahid (Gus Dur) states that tolerant attitude is more about affair of every person's heart and behavior. In this context Gus Dur develop a view of anti exclusivism in religion, a view refusing unrest, violence and radikalism. This inclusive thinking emphasizes the struggle and the spread of Islam culturally presenting moderate and tolerant face for the other religion existence, and ideology out of Islam as an inspiration source for the creation of justice system in the Indonesian state system. ${ }^{19}$ This thinking model known as 'Islam indigenization' (pribumisasi Islam), a concept that seeks conciliation form between religion and culture.

17Ngainun Naim and Achmad Sauqi, Pendidikan Multikultural; Konsep Dan Aplikasi, (Jakarta: ar-Ruzz Media, 2011), 77

${ }^{18}$ Azyumardi Azra, Islam Indonesia Berkelanjutan, in Kompas Opinion, 3 Agustus 2015

${ }^{19}$ Abdurrahman Wahid, Dialog Agama Dan Masalah Pendangkalan Agama Dalam Komaruddin Hidayat Dan Ahmad Gaus, (Jakarta: Gramedia Utama, 1998), 52 
Historically this trend can be traced from the Islamization process itself identical to the cultural approach. First, the trade media. Islam was introduced by traders who expected occur approximately in 7-13 century AD. ${ }^{20}$ Islamization channel by this way is very helpful in shaping the attitude and style of religion that ultimately considered in awareness communally normatively there is no distigsion in Islam, namely the distinction between trading activities with the obligation to preach Islam. Another benefit is the easy of Islamization itself where the kings and nobles also involved in it, so this form of socialization created an interactional image of peace in a pluralistic society spectrum. ${ }^{21}$

Kenneth W. Morgan explains that the information validity of Islamization beginning in Indonesia can be referred to the saying of Marcopolo that many people in Perlak (a city on the northern coast of Sumatera) were Islamized by traders called Saracens around 1912 AD. This assumption is based on the experience of Marcopolo himself in his passage back to Venice in 692 (1292 AD), Marcopolo has stayed over in Perlak for five months. ${ }^{22}$

Secondly, marriage. This marriage occurs as a result of trade interaction with local population, traders or Muslim merchants mating with local women, so that the Islamization process has become very easy because marriage itself is a bond spiritually connecting one another emotionally. From this relationship they create a core of Muslim families which then tie larger kinship. ${ }^{23}$

Third, Politic of king power Influence. This channel is very influential for the Islamization process in this country, by structural rationalization that the king converting in Islam will be followed, lead of the king in the same religion as a form of obedience. It is based on the understanding that culturally people have very high adherence to the king, becouse he is regarded as a role model for his people. Such as in South Sulawesi and Maluku, many people convert to Islam after

\footnotetext{
${ }^{20}$ Hasan Muarif Ambary, Menemukan Peradaban Jejak Arkeologis dan Historis Islam Indonesia (Jakarta: Logos Wacana Ilmu, 2001), 53

${ }^{21}$ Nor Huda, Islam Nusantara, Sejarah Sosial Intetelektual Islam di Indonesia, Jogjakarta: ar-Ruzz Media, 2007, 45

22P.A. Hoesain Djajadiningrat, Tinjauan Kritis Tentang Sejarah Banten, (Jakarta: Pustaka Jaya, 1983), 119

${ }^{23}$ Nor Huda, Islam Nusantara, 46
} 
the king first. ${ }^{24}$ It is biase of traditional hierarchical principles which ensure the king influence in his converting to Islam, that will be followed by majority of his people.

Fourth, Sufism. Sufism also includes media that shapes Indonesian social life and leave lot of clear evidence, in the form of texts between the 13th and 18th century related to the spread of Indonesian Islam directly and holds most important role in the organization of society. Not infrequently this Sufism is tailored to local mystical teachings that have been established by HinduBuddhist culture. They try to integrate Islamic teaching suitable to the local communities minds so that islamic teachings and local beliefs do not clash. Among the experts who formulate teachings of Sufism and contain similarities to the natural mind (mystical) of Indonesian society is Hamzah Fansuri, Syamsudin al-Sumaterani, and Sunan Panggung. They are willing to put the elements of pre-islamic culture to spread Islamic religion it self, such as Java teachings about Bimasuci adapted into a saga Syech Maghribi. ${ }^{25}$

Fifth, Art becomes other tools that mediate the spread of Islam such as architecture, sculpture, dance, music and literature. we can see many proofs that can be lifted to the surface, such as mosque of Demak Sendang Duwur in Cirebon, Banten Grand Mosque, Baiturrahman in Aceh, Ternate, and so on. ${ }^{26}$ In other hand, some other art examples are wayang and gamelan being used as cultural media to invite people for seeing the show while inserted the introduction and preaching Islamic teachings inside. ${ }^{27}$

Sixth, education media. This media obviously has a big role in the islamization process. Suitable for the time context, people need a place or institution to accommodate their children in order to improve and deepen their knowledge. It is bridged by the beginning propagator of Islam namely as Sunan Ampel in Ampel Denta. ${ }^{28}$ This medium Form creats many Islamic schoolars (ulama') who able to expand Islam into different areas and survive until today.

24Uka Tjandrasasmita (Ed.), Sejarah Nasional Indonesia III, (Jakarta: PN Balai Pustaka, 1984), 205.

${ }^{25}$ Nor huda, Islam Nusantara, 47

26Uka Tjandrasasmita (Ed.), Sejarah Nasional, 205.

27Ibid.

${ }^{28}$ Nor Huda, Islam Nusantara, 47 
These approach system and Islamic education are brilliant struggle implemented by simple expedient especially by showing new alternatives that do not disturb the traditions and local customs, as well as easily grasped by laymen, for their approach (propagator of Islam) is really concrete, realistic and merge with community life. These efforts in modern concept is often known as a model of development from within That able to absorb local and foreign culture, but at the same time still stand firmly on the principles of Islam which known as kuwalen era, namely a victory in peace. ${ }^{29}$

\section{Islam Nusantara In Islamic Law Epistemology Overview}

The arise question whether Islam nusantara or islamic model as taught by Walisongo and practiced by most Javanese community can be called a pure Islam or Islam kâffah? To answer this question, it's need to explore some basic arguments clearly.

Basically, Islam is a value that normatively should be believed as way of life in various dimensions. The existence of this value is not limited to one group of people only, but for all mankind as confirmed in Q.S (7):158

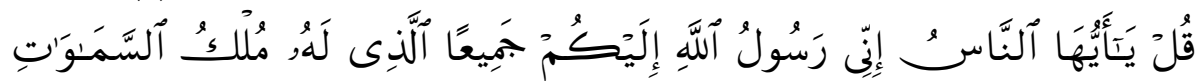
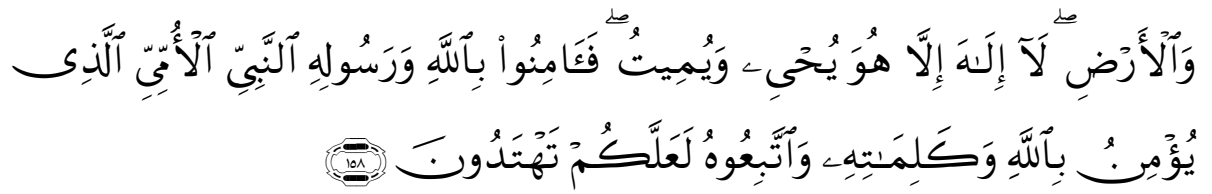

Say (O Muhammad): O mankind! I am the messenger of Allah to you all - (the messenger of) Him unto Whom belongeth the Sovereignty of the heavens and the earth. There is no Allah save Him. He quickeneth and He giveth death. So believe in Allah and His messenger, the Prophet who can neither read nor write, who believeth in Allah and in His Words, and follow him that haply you may be led aright. ${ }^{30}$

In other verse
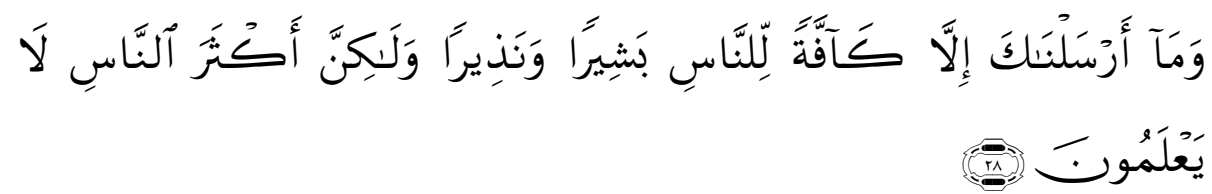

\footnotetext{
29Ibid.

30Departemen Agama, al-Quran dan Terjemahnya, (Jakarta: PT Bumi Restu, 1976), 247
} 
And We have not sent you (O Muhammad) only as a bringer of good tidings and a warner unto all mankind; but most of mankind do not know. ${ }^{31}$

In this text clarity, Allah ordered Prophet Muhammad to declare himself as a messenger who is sent to all mankind. Ibn Kastir in his commentary explains that yâa ayyuha al-nâs (O mankind) is khithâb (appeal) to all humanbeing in the entire universe either red skin, blacks, Arabs and non-Arab ('ajamî). Further Ibn Kathir explains that Prophet Muhammad is a seal of overall prophets or the last prophet that there will be no prophet again after him. ${ }^{32}$

Some verses above provide a logical consequence that Islam as a religion brought by Prophet Muhammad to be preached for all mankind throughout the world. This fact also indicates an obligation for every Muslim to preach and invite other people to believe in Allah as the only God and Muhammad as a prophet and messenger, as confirmed in His Word Q.S al-Anbiya (21): 107

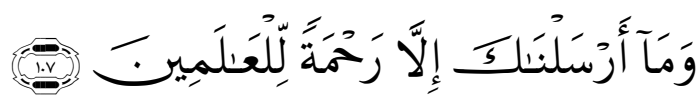

"And We have not sent you (Muhammad) but to (become) a mercy to all the worlds".33

This logical consequence of Islamic universality is the fact that Islam face various forms of human civilization in space and different time. On the other hand, according to Fazlur Rahman, historically the main source of Islam is divine revelation contained in a book called alQuran. However, the book did not go down once in unison, but little by little and only collected after several years. Therefore, the revelation of this type is the reaction of social-historical conditions that took place at that time. The relationship between followers and revealed text was made possible by normative aspect of the revelation, while the pattern walked through on interpretations (exegesis). The text never speak for itself, and it would be meaningful if it is connected with humans. What is done, approved, and said by prophet is the effort result (ijtihad) in understanding normative

\footnotetext{
31Ibid., 688

${ }^{32}$ Abil Fida' Ismail ibnu Katsîr, Tafsîr al-Qur'ân al-Karîm, Jilid 2, (Semarang: Thaha Putra, tt), 254

33Departemen Agama, al-Quran dan Terjemahnya, 508
} 
dimension of revelation. Meanwhile, the prophet interpretation efforts is affected by historical situation in particular time. ${ }^{34}$

Azyumardi Azra stated that no culture in the world is not syncretic, because all cultures certainly have historical aspect that are not sole and thus are syncretic. ${ }^{35}$ Neither religion nor culture can not circumvent from the unavoided process, namely the change. It is true, the teaching of religion as stated textually in scripture, word for word remains as original condition. However, when religious teachings should be understood, interpreted and translated into real action in cultural, political, economic specific setting, at that time the understanding based on religious teachings basically turned into culture. ${ }^{36}$

The cultural plurality of religions can not be avoided when the religion had spread so wide with diverse cultures background. In the interaction and dialogue between religious teachings with the more localized culture, the strength or weakness of cultural roots will really determine how deep and strong the universal religious teachings reach local socio-cultural realities. ${ }^{37}$

This approach is introduced in Q.S al-A 'raf (7):199

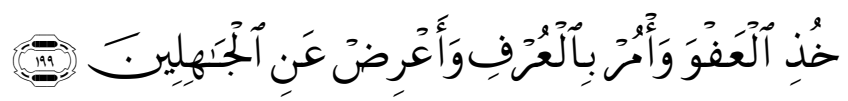

"Take what is given freely, enjoin what is good, and turn away from the ignorant". 38

Quraish Shihab interpretates that al-urf same as ma'ruff, which is something known and justified by public such as customs are supported by common sense and do not contradict with religious teachings premises. it is a clear virtue and known by everyone as well as well-received by normal human beings. It is agreed, so do not need to be discussed moreover contended for. Quraish Shihab tells that Surat al-Imran (3): 104 using the term 'khair' to show universal and fundamental values of divine revelation, and being local and temporal

34Hendro Prasetyo, "Mengislamkan Orang Jawa: Antropologi Baru Islam Indonesia”, Islamika No.3, Januari-Maret 1994, 75.

${ }^{35}$ Alwi Shihab, Islam Inklusif: Menuju Sikap Terbuka dalam Beragama, (Bandung: Mizan, 1997), 314.

36Bambang Pranowo, Islam Faktual: Antara Tradisi dan Relasi Kuasa, (Yogyakarta: Adicita, 1999), 20.

37Ibid., 19

38Ibid., 255 
values named 'ma'rûf. Khayr is not imposed while ma'rûf is conspiration result, so it can vary from one society to another, even from one time to another time in the community. By this concept of $m a^{\prime} r \hat{u} f$ The Koran open wide door to accommodate the change in value due to positive development of society. This is achieved because the imposed value or not in line with the cultural development of society will not be applied. It should be noted that the concept of $m a^{\prime} r \hat{u} f$ just opened for positive development of society, not a negative development. 39

The references of Islam Nusantara in hadiths perspective can be traced from the methods of prophet Muhammad propaganda, where he has always respected the effective local traditions and occasionally revise or reject as whole if they are contrary to the principles of Islam. One of them, as described in the hadith below narrated by imam Bukhari from Ibn Abbas:

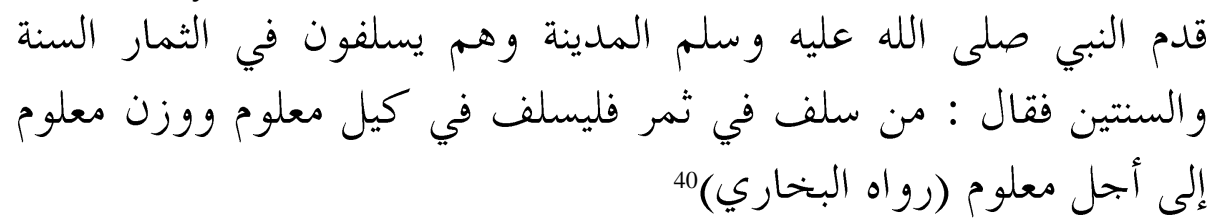

The Prophet Muhammad SAW came in Medina, they (the people of Medina) had been used to give an advance on fruits for a year or two years, then the Prophet said: "Whoever give the down-payment (advance) on the fruit, give it in certain doses, certain scales and definite time."

This hadith appears that Prophet Muhammad really appreciate already exist tradition and does not change it at all. This means that every tradition still in accordance with the values of Islam, has to be maintained, as also supported by other hadits:

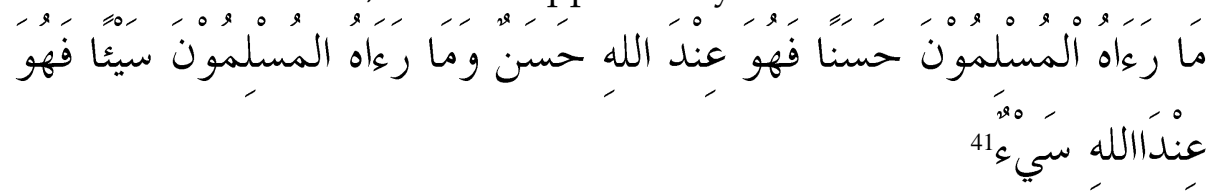

${ }^{39}$ M. Quraish Shihab, Tafsir al-Mishbah; Pesan, Kesan dan Keserasian al-Quran, (Tangerang: Lentera Hati, 2005), 353

${ }^{40}$ Muhammad bin Isma'îl al-Amîr al-Yamânî al-Shan'ânî, Subul al-Salâm, Jilid 3 (Kairo: Dârul Hadîts, 2007), 66

${ }^{41}$ Abû 'Abdillâh al-Hakîm Muhammad bin 'Abdillâh, al-Mustadrak 'Alâ Shahîhayn, (Bairut: Dârul Kitâb al-'Ilmiyah, 1990), 83 
"Everything regarded as good thing by Muslims, it's also good in the sight of God, and the everything regarded as bad thing by Muslims it also classed as a bad by God " (HR. Ahmad, Bazar, Thabrani in a book al-Kabir from Ibn Mas'ud).

This hadith becomes a proof that every tradition still has good value and relevant to the Islamic principles is acceptable as a part of Islam. In Islamic law epistemology (usul figh), tradition and custom of society has gained recognition as religious guidance in establishing a law. Something known as' 'urf (mentioned above) as classical concept that explores local tradition, the habit of humanbeing running communally and distributed among them, so that it becomes a special identity. ${ }^{2}$

Conceptually, 'urf is divided into two parts between shahîh and fâsid. 'Urf shahîh is something habit mutually known by humanbeing, and not contrary to the arguments of syara', does not justify something forbidden, and does not cancel something obligation such as their habit to held contract of production services and so forth. 'Urf fâsid is something that has become tradition of humanbeing, but contrary with syari'ah, such as some habits of eating usury treasure, gambling, and so on. ${ }^{43}$

This law can be changed according to the change of the place, for the real a branch will change suitable for the change of it principle. On the other hand 'urf is not a proposition standing without regard to other legal aspects. Especially 'urf closely related to maslahah mursalah that puts the common kind as a priority. ${ }^{44}$ The principle of maslahah is not personal, but collective in which society become common goal for the greater common kind. The establishment of this law is not meant except for creating kindness crowd, and this kindness continuously emerges on the update situation of community and grow due to differences of environment. 45

Al-'âdah muhakkamah is a form of normative justification recognized by the scholars' stating that priests, customs, tradition occuring repeatedly in the community can also be used as legal. ${ }^{46}$ Rule of Fiqh and it development is solely aimed at the achievement of

42Wahbah al-Zuhaylî, Ushûl al-Fiqh al-Islâmî, (Bairut: Dârul Fikr, 1998), 829

${ }^{43}$ Abdul Wahhab Khallaf, Ilmu Ushul Figh, (Semarang: Dina Utama, 1994), 123

44Ibid.

45Ibid., 116.

46Ahmad al-Nadawî, al-Qawấ'id al-Fiqhiyah, (Bairut: Dâru al-Qalâm, tt.), 293 
maqâshid al-syarî'ah (law purposes), namely the realization of people kindness (maslahah) in the world and hereafter, an expediency under the auspices of five principles (al-Kulliyat al -khams), namely hifd aldîn, hifd al-nafs, hifd al-'aql, hifd al-mâl, and hifd al-nasl.47

In this context, nushîsh al-syarî'ah, the text of Shari'a that is understood by observing maqâshid al-syarî'ah will creat law that not always textually but also contextual-empirical. ${ }^{48}$ Aside from Nuzĥu alSyarî'ah and maqashid al-sharia, Islam also has Mabâdi' al-Syarî́ah (the principles of shari'ah). One of the principles of Shari'a and most important as well as the characteristic of Islam is al-Wasathiyyah (Moderate). This is stated directly by God in His word,

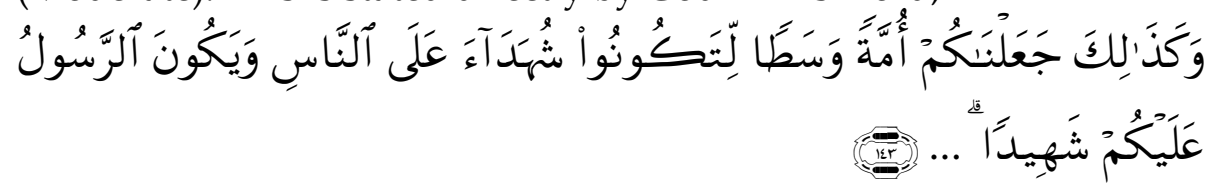

And thus we have made you a just community that you will be witnesses over the people and the Messenger will be a witness over you. (al-Baqarah: 143) ${ }^{49}$

Wasathiyyah often translated into Indonesian by "moderation", compromise and mediation, ${ }^{50}$ which means getting settle in a neutral position, not at the extreme positions neither top nor bottom extreme, so the implications of this positions is the formation of compromise attitude, fair and wise in facing dynamical life reflecting the Islamic life peacefully.

\section{Closing}

Concept of Islam nusantara was born from the womb of NU to strengthen Islam rahmatan lil'âlamîn implemented in the forms of value and peaceful social interaction. This islamization pattern is closely related to the effort to synthesize Islamic values with Indonesian local traditions in the form of internalization or value assimilation as long as not contrary to the religion spirit as practiced by walisongo. The implication of this pattern is moderation character and tolerance in

47Nuruddîn bin Mukhtâr al-Khâdimi, Ilmu al-Maqâshid al-Syar'iyatî, Riyadl: Maktabah al-'abikân, 1997, 15

48 Ibid.

49 Depatemen agama, al-Quran, 36

${ }^{50}$ Atabik Ali dan A. Zuhdi Muhdlor, al-'Asrî; Kamus Kontemporer Arab Indonesia, Krapyak: Multi Karya Grafika, 1999, 2016 
the nation plurality frame with a sense of mutual respect and appreciate one another.

On the other hand, this approach is estimated as a necessity that has been accommodated in the Islamic law epistemology, saying that the tradition of society being received together is part of the law itself. This law simplification is' 'urf, which is a good habit that does not deviate from the prime justification of al-Quran and Hadith. Therefore, Islam Nusantara is not a concept coming out from the Islamic law itself.

\section{References}

Ali, Atabik dan A. Zuhdi Muhdlor, al-'Asri; Kamus Kontemporer Arab Indonesia, Krapyak: Multi Karya Grafika, 1999

Azra, Azyumardi. Asia Tenggara Konsentrasi Baru Kebangkitan Islam, Bandung: Fokusmedia, 2003

Ambary, Hasan Muarif. Menemukan Peradaban Jejak Arkeologis dan Historis Islam Indonesia, Jakarta: Logos Wacana Ilmu, 2001

Nadawî, Ahmad al-. al-Qawấ'id al-Fiqhîyah, Bairut: Daru al-Qalam, tt. Zuhaylî, Wahbah al-. Ushûl al-Fiqh al-Islâmiy, Bairut: Darul Fikr, 1998

Boenawi, Rofii. Inilah Calon Pemimpin Kita, Surabaya: PT Aula Media Nahdlatul Ulama), Majalah Nahdlatul Ulama' AULA edisi Juli 2015

Djajadiningrat, P.A. Husein. Islam di Indonesia, Jakarta: Pustaka Jaya, 1986 Tinjauan Kritis Tentang Sejarah Banten, Jakarta: Pustaka Jaya, 1983

Feillar, Andree, NU vis a vis Negara, Jogjakarta: LkiS, 1999

Huda, Nor. Islam Nusantara, Sejarah Sosial Intelektual Islam di Indonesia, Jogjakarta: ar-Ruzz Media Group, 2007

Hurgronje, C. Snouck. Arti Agama Islam Bagi Penganutnya di Hindia Belnda, Dalam Kumpulan Karangan Snouck Hurgronje, jilid VII, terj. Sutan Maimun dan Rahayu S. Hidayat, Jakarta: INIS, 1994

Ismail, Faisal. Pijar-Pijar Islam, Pergumulan Kultur Dan Struktur, Jakarta: Badan Litbang Agama dan Diklat Keagamaan, tt.

Ibn 'Abdillah, Abu Abdillah al-Hakim Muhammad. al-Mustadrak 'Alâ Shahihaini, Bairut: Darul Kitab al-Ilmiah, 1990

Khallaf, Abdul Wahhab. Ilmu Ushul Figh, Semarang: Dina Utama, 1994 
Kuntowijoyo. Muslim Tanpa Masjid: Esai-Esai Agama, Budaya dan Politik Dalam Bingkai Strukturalisme Transendental, Bandung: Mizan, 2001

Katsir, Abil Fida' Isma'îl Ibn. Tafsir al-Qur'âni al-Karîm, Jilid 2, Semarang: Thaha Putra, tt

Maksum, Ali, Pengantar filsafat, Jogjakarta: ar-Ruzz Media, 2011

Mas'ud, Abdurrahman, Dari Haramain ke Nusantara Jejak Intelektual Arsitek Pesantren, Jakarta: Kencana Prenada Media Group, 2006

Mahmudunnasir, Syed, Islam: Konsep dan Sejarahnya, Bandung: PT. Remaja Rosdakarya, 2011

Ni'am, Syamsun, Pesantren: The Miniature of Moderate Islam in Indonesia, IJIMS, Indonesian Jurnal of Islam and Muslim Societies, volume 5, 1 Juni 2015

Purwadi, Dakwah Sunan Kalijaga; Penyebaran Agama Islam di Jawa Dengan Berbasis Kultural, Yogyakarta: Pustaka Pelajar Offset, tt

Shan'âniy, Muhammad bin Isma'îl al-Amîr al-Yamâniy al-. Subulu alSalâm, Jilid 3, Kairo: Dârul Hadits, 2007

Shihab, M. Quraish, Tafsir al-Mishbah; Pesan, Kesan dan Keserasian alQuran, Tangerang: Lentera Hati, 2005

Sofwan, Ridin, dkk., Islamisasi di Tanah Jawa; Walisongo Penyebar Islam di Jawa Menurut Penuturan Babad, Yogyakarta: Pustaka Pelajar, 2000

Suryanegara, Ahmad Mansur, Menemukan Sejarah: Wacana Pergerakan Islam di Indonesia, Bandung: Mizan, 1998

Tjandrsasmita, Uka, Pertumbuhan Dan Perkembangan Kota-Kota Muslim di Indonesia; Dari Abad XIII Sampai XVIII Masehi, Kudus: Menara Kudus, 2000

Tjandrasasmita, Uka (Ed.), Sejarah Nasional Indonesia III, Jakarta: PN Balai Pustaka, 1984 